\title{
Thermal Evaluation of a Hybrid Dryer with Solar and Geothermal Energy for Agroindustry Application
}

\author{
Emérita Delgado-Plaza ${ }^{1} * \mathbb{C}^{\mathbb{D}}$, Juan Peralta-Jaramillo ${ }^{1}$, Miguel Quilambaqui ${ }^{1}$, Olga Gonzalez ${ }^{1}$, \\ José Reinoso-Tigre ${ }^{1}$, Anthony Arevalo ${ }^{1}$, Mirari Arancibia ${ }^{2}$, Mayra Paucar ${ }^{2}$ \\ and Borja Velázquez-Martí ${ }^{3}$ (D) \\ 1 ESPOL Polytechnic University, Escuela Superior Politécnica del Litoral, ESPOL, FIMCP-CDTS, Campus \\ Gustavo Galindo Km, 30.5 Vía Perimetral, Guayaquil P.O. 09-01-5863, Ecuador; jperal@espol.edu.ec (J.P.-J.); \\ mquilab@espol.edu.ec (M.Q.); omgonzal@espol.edu.ec (O.G.); josirein@espol.edu.ec (J.R.-T.); \\ afareval@espol.edu.ec (A.A.) \\ 2 Mecánica, Ingeniería en Alimento, Universidad Técnica de Ambato, UTA, Av Mexico y Salvador, Ambato \\ P.O. 180104, Ecuador; marancibias@uta.edu.ec (M.A.); ma.paucar@uta.edu.ec (M.P.) \\ 3 Departamento de Ingeniería Rural y Agroalimentaria, Universitat Politècnica de València, Camino de Vera \\ s/n, 46022 Valencia, Spain; borvemar@dmta.upv.es \\ * Correspondence: eadelgad@espol.edu.ec
}

Received: 15 August 2019; Accepted: 25 September 2019; Published: 30 September 2019

\begin{abstract}
The process of drying at the agroindustry level is considered the most important stage for the storage and conservation of food, but an inadequate sizing of the systems can generate an excessive consumption of fuel and energy. In the case of the agricultural sector, especially in small and medium producers in Ecuador, they tend to dry cereals outdoors, spreading the product over black plastics, asphalt floors, or cements called "tendal". This process depends on the weather conditions of the area and can take between one or four days of drying, tending to damage the product by fungi. On the other hand, certain producers build dryers empirically, using as the main fuel gas for domestic use, diesel, or firewood. Among the problems presented for these types of dryers are heat losses in the drying chamber as it is not thermally insolated, a lack of temperature control (above $60^{\circ} \mathrm{C}$ ) and drying speed, excessive fuel use, and $10 \%$ burned product, which are essential to control to obtain a quality product and savings in the energy consumption of the dryer. With regard to the problem raised above, the design and construction of a hybrid dryer that worked with $80 \%$ of thermal solar and low enthalpy aerogeothermal energy and $20 \%$ with electric power was conducted to optimize the drying process and ensure a quality dry product. The work proposes the dimensioning of each component of the dryer. As a result, it was found that the efficiency of the equipment was around $60 \%$, reaching a maximum operating temperature of $52{ }^{\circ} \mathrm{C}$, with a stabilization time of the system in the first hour within $40 \mathrm{~min}$. It should be noted that the design of the prototype is easy to adapt and replicate.
\end{abstract}

Keywords: hybrid dryer; aerogeothermal; agroindustry

\section{Introduction}

Dehydration of a food consists of the extraction of water from the product with the aim to preserve it for much longer [1]. To achieve this process, drying equipment that requires a constant source of heat such as electrical resistors, biomass boilers, gas burners, and diesel burners, among other options, are used within the context of the industrialized framework. In the same vein, the small producers harvesting between 90 and $909 \mathrm{~kg}$ of cereals use wood, LPG (liquefied petroleum gas), coal, solar energy, among others, as an energy source for drying. 
It should be noted that the use of the selected energy source depends on the temperature, speed, and drying time of the product as well as the type of product to be dehydrated to avoid damaging its molecular structure and therefore its nutritional quality.

It is estimated that the energy required to dry grains, depending on the drying temperature, ranges from 3000 to $8000 \mathrm{~kJ} / \mathrm{kg}$ of water removed [2]. Likewise, the type of drying system as well as the quality and humidity of the grain can considerably affect the energy demand of the process. In relation to the evaluation of the energy efficiency of the process, several authors have reported in general terms that the consumption heat to dry grains varies between 2330 to $2790 \mathrm{~kJ} / \mathrm{kg}$ of water eliminated when natural air is used, while on the other hand, when an artificial source of air is used (turbulent flow), this rate varies between 2790 to $3490 \mathrm{~kJ} / \mathrm{kg}$ of evaporated water. Finally, for Batch-type dryers, the evaporation rate is usually 3490 to $4650 \mathrm{~kJ} / \mathrm{kg}$ of evaporated water, and for high-temperature dryers without recirculation, the rate is 4650 to $6980 \mathrm{~kJ} / \mathrm{kg}$ of evaporated water [3]. These values can present important fluctuations in the drying equipment, depending on the technological parameters and operation including energy vectors, which causes a significant increase in the final energy consumption [2,3].

In 1996, the Food and Agriculture Organization (FAO published in the booklet9 "Post-harvest Technology" in the document entitled "drying of grains and dryers", the basic procedures for the evaluation of drying behavior at the industrial level. This document highlights that there are two procedures. The first procedure consists of the realization of technical tests under norms or regulations previously recognized by accredited institutions with a high cost of execution. The second procedure, of lower cost, is based on gathering information from the data provided by the manufacturers themselves in their manuals or brochures or those that are acquired through direct contact with the owners of the dryers.

In the case of Ecuador, the existing information in relation to the energy evaluation of the drying technology associated with the design and construction of prototypes based on the use of renewable energy sources for cereal drying is minimal. Likewise, it is necessary to indicate that many dryers in the agroindustry sector in Ecuador are of the artisanal or semi-artisanal type. These dryers have problems due to not controlling the temperature and drying speed by the hot gas in the chamber. This causes inhomogeneous drying, and the extra consumption of fuel unnecessary for its operation.

Another important point of the current problems of drying in Ecuador is the need to build dryers with national materials to avoid the importation of Brazilian, German, Indian, Colombian and Chinese dryers, which have an approximate cost $\$ 7700$ dollars (the reference value includes the import cost) for a capacity of $909 \mathrm{~kg}$ of product. In any case, local construction will reduce the cost of the dryer by about $50 \%$. It could even regulate different drying temperatures $\left(40{ }^{\circ} \mathrm{C}, 50^{\circ} \mathrm{C}\right.$, and $\left.60{ }^{\circ} \mathrm{C}\right)$ with the purpose that it can be used to dry any type of product (rice, wheat, corn, cocoa) [4]. Finally, during the research phase, it was determined that a handcrafted dryer built with materials such as cement and brick would cost $\$ 500$ dollars for a capacity between 227 to $454 \mathrm{~kg} /$ day of product.

At the Ecuadorian agro-industrial level, the drying of product is usually done in square or rectangular chambers, made with masonry materials in its structural part (bricks and cements). They are used as trays, jute bags, or plates of perforated stainless steel. The ducts and pipes for the entry of air are built with stainless steel plates. On the other hand, there are circular camera dryers, which work with a LPG burner and an extractor, where the dimensions of the equipment depend on the drying capacity. Additionally, rotary dryers and electric dryers (operating temperature between 100 to $120^{\circ} \mathrm{C}$ ) are also used.

It is necessary to indicate the reality of the agricultural sector that for small products, drying of the product is carried out by spreading out the product on a concrete or plastic floor and exposing it to the sun (tendals) for several days. The use of technology is not cost effective for this sector given the cost of fuel and electricity that is needed to dry the product for 6 or $12 \mathrm{~h}$. The added problem of the use of tendal is the contamination of the agricultural product by dust, emissions of vehicle gases, animals, and people stepping on the product. 
During the study presented by Delgado 2018, it indicated that the problem of drying technology is caused by the inadequate distribution of hot air throughout the chamber $(0.3 \mathrm{~m} / \mathrm{s}$ to $4 \mathrm{~m} / \mathrm{s})$ and lack of control of flame temperature (use of LPG, $280^{\circ} \mathrm{C}$ to $600^{\circ} \mathrm{C}$ ), which generates an over-sizing of an air extractor (air speed between 8 to $13 \mathrm{~m} / \mathrm{s}$ ), so that the drying temperature of the product reaches between 50 to $60^{\circ} \mathrm{C}$. In economic terms, it is estimated that drying $450 \mathrm{~kg}$ of product with about $40 \%$ initial moisture content to $10 \%$ moisture content after $8 \mathrm{~h}$ consumes $250 \mathrm{kWh}$ electric ( $\$ 25$ dollars) and between $45 \mathrm{~kg}$ and $90 \mathrm{~kg}$ of gas ( $\$ 12$ dollars).

An estimate of the electricity and gas consumption is presented below in Table 1 of the different drying capacities [5].

Table 1. Estimate of electricity and industrial LPG consumption.

\begin{tabular}{cccc}
\hline Drying Capacity (kg) & $\begin{array}{c}\text { Electricity } \\
\text { Consumption (kW) }\end{array}$ & $\begin{array}{c}\text { Electricity } \\
\text { Consumption (dollars) }\end{array}$ & $\begin{array}{c}\text { Industrial LPG } \\
\text { Consumption (dollars) }\end{array}$ \\
\hline $909-1363.6$ & 437.5 & $\$ 50$ & $\$ 150$ \\
$1363-1818$ & 500 & $\$ 75$ & $\$ 250$ \\
$1363.6-1818$ & 640 & $\$ 190$ & $\$ 500$ \\
\hline
\end{tabular}

Finally, the above values vary from the drying time and the initial and final moisture of the product. Inappropriate energy management in the drying process can influence the product's marketing chain, causing fluctuations in the final price. As a result, industries where food products are processed will need to establish energy efficiency actions for their processes in the future in order to improve their operations and thus ensure the competitiveness of their products. For this reason, the objective of this work was to assess the function of a hybrid dryer with solar and geothermal energy for agroindustry application as a technological alternative to allow for energy savings and ensure that a final quality product is obtained, based on the control of the temperature and air speed of the equipment $[4,5]$.

\subsection{Hybrid Dryer Sizing}

\subsubsection{Drying Chamber (Solar Energy as Main Source)}

Prior to the design of the experimental prototype, it is necessary to consider the following significant parameters that will influence the operation of the dryer to reach an acceptable efficiency of 40 to $50 \%$ of energy saving and obtain a uniformly dehydrated product [6-8].

- Product: thickness, drying temperature, wet weight, drying speed diagram, dry weight, thermal conductivity, dry-Bulb humidity, and drying time;

- Solar energy resources in the area;

- Dryer: dryer type, length, total area, construction material, material conductivity, wall thickness, heat transfer coefficient by convection, radiation, and conduction;

- Heat transfer mechanism: temperature, hot air humidity, speed, saturated air humidity, flow conditions (laminar or turbulent), latent vaporization heat, tray area, and conduction heat transfer coefficient in the trays;

- Variables associated with thermal operation: energy consumption, drying efficiency, and dryer efficiency;

- Handling and easy construction; and

- Cost of investment and operation.

The design of the tray dryer will have a drying capacity of $7 \mathrm{~kg}$. Metallic materials for the construction of the side walls and floor are intended, and the front wall and ceiling will be made of transparent polycarbonate plates $(0.6 \mathrm{~cm}$ thickness of the plate). The transparent material will allow us to take advantage of the solar irradiation of the day, bringing heat to the system. 
To calculate the total energy needed to evaporate $45 \%$ of the product's water content, the methodology of the analysis of heat loss and gain in the chamber was used as well as the analysis of mass and heat transfer to the product [6,7].

The total energy used, $Q_{T}$ is determined by the summation of all losses and energy consumption in the form of heat needed by the chamber from its pre-heating, the evaporation of the product water, and loss of heat by the walls (structure) until the renewal of the air inside the drying chamber $[8,9]$.

$$
Q_{T}=\sum Q_{1-6}
$$

Initial heating of the equipment $Q_{1}$ (kcal)

$$
Q_{1}=V_{\text {prod }} d_{\text {prod }} X_{i} C_{p, \text { prod }}\left(T_{a, c}-T_{a}\right)
$$

where $V_{\text {prod }}$ is the product volume; $d_{\text {prod }}$ is the product density; $T_{\text {prod }}$ is the product temperature; the material specific heat $C_{p \text {,prod }}=0.265+0.001 \mathrm{Tproduct}\left(\mathrm{kcal} / \mathrm{kg}{ }^{\circ} \mathrm{C}\right) ; X_{i}$ is the initial air humidity; $T_{a c}$ is the heating temperature $\left({ }^{\circ} \mathrm{C}\right)$; and $T_{a}$ is the initial air temperature $\left({ }^{\circ} \mathrm{C}\right)$.

Heat required to raise the air temperature inside. $Q_{2}(\mathrm{kcal})$

$$
Q_{2}=V_{a, c} d_{a, c} C_{p a, c}\left(T_{a, c}-T_{a}\right)
$$

where $V_{a, c}$ is the camera volume $\left(\mathrm{m}_{3}\right) ; d_{a, c}$ is the air density $\left(\mathrm{kg} / \mathrm{m}^{3}\right)$; and $C_{p a, c}$ is the specific heat of the air $(\mathrm{kcal} / \mathrm{kg} \mathrm{C})$.

Heat needed for water evaporation. $Q_{3}(\mathrm{kcal})[10]$.

$$
Q_{3}=V_{\text {prod. }} d_{\text {prod. }}\left(X_{i}-X_{f}\right) \lambda_{w}+5(\mathrm{kcal} / \mathrm{kg}) * V_{\text {prod. }} d_{\text {prod. }}
$$

where $V_{\text {prod }}$ is the product volume; $d_{\text {prod }}$ is the product density; $X_{i}$ is the initial air moisture content; $X_{f}$ is the final air moisture content ( $\mathrm{kg}$ water $/ \mathrm{kg}$ dried air); and $\lambda_{w}$ is the latent heat of evaporation $(\mathrm{kcal} / \mathrm{kg})$.

Heat lost by structure $Q_{4}(\mathrm{kcal})$

$$
Q_{4}=U A\left(T_{a, c}-T_{a}\right)
$$

where $U$ is the overall heat loss ratios determined by the convection coefficients $h i$ and $h e\left(\mathrm{~W} / \mathrm{m}^{2} \mathrm{~K}\right)$; conduction $k(\mathrm{~W} / \mathrm{m} \mathrm{K})$ and radiation $h r\left(\mathrm{~W} / \mathrm{m}^{2} \mathrm{~K}\right) ; U=1 /(1 / h i+e / k+1 /(h e+h r))$. $A$ is the chamber area. $T_{a, c}$ is the chamber operating temperature and $T_{a}$ is the outdoor ambient air temperature.

To determine the combined convection and radiation coefficient on the outside of the chamber, we applied the equation of McAdam, where $(h e+h r)=h e x c, r=5.7+3.8 \mathrm{va}$, and va is the ambient air velocity.

Heat needed for chamber heating $Q_{5}(\mathrm{kcal})$

$$
Q_{5}=\left[\left(V * d * C_{p}\right)_{\text {polycarbonate }}+\left(V * d * C_{p}\right)_{\text {metal }}+\left(V * d * C_{p}\right)_{\text {insulation }}\right] \Delta T
$$

where $V\left(\mathrm{~m}^{3}\right)$ is the volume; $d\left(\mathrm{~kg} / \mathrm{m}^{3}\right)$ is the density; $C_{p}\left(\mathrm{kcal} / \mathrm{kg}{ }^{\circ} \mathrm{C}\right)$ is the calorific power; and $\Delta T$ is the difference between the ambient temperature and hot air temperature.

Heat needed for air renewal $Q_{6}(\mathrm{kcal})$.

$$
Q_{6}=V_{\text {prod }} d_{\text {prod }}\left(X_{i}-X_{\text {final }}\right) C_{p a, c}\left(T_{a, c}-T_{a}\right)
$$

The saturated air is constantly renewed by a fan that will pass through an electrical resistance, allowing the air temperature to be raised to the optimal drying conditions. It should be noted that the 
complementary electrical resistance system should only be activated in case the climatic affectation has days of low irradiation where the dryer does not reach the operating temperature.

Drying velocity

Once the total heat required to dry $7 \mathrm{~kg}$ of wet product is obtained, the air speed required to reach the operating temperature and pass hot air evenly through the trays is determined [10].

$$
v_{\text {entrada }}=\frac{Q_{T}}{C_{p} *\left(T_{a, c}-T_{s}\right) x\left(d_{a, c} * A\right)}
$$

where $Q_{T}$ is the total heat; $C_{p}$ is the air-specific heat; $T_{a, c}$ is the hot air temperature in the chamber; $T_{s}$ is the temperature on the surface of the product; $d_{a, c}$ is the air density; and A is the hot air inlet area.

Dryer thermal efficiency

The energy efficiency of the drying process is determined from the energy consumption supplied with respect to the evaporated water. The equation commonly used to obtain the efficiency of the dryer is indicated below [11].

$$
\varepsilon=\frac{\text { Total energy supplied }}{\text { energy used }+ \text { energy lost in the hot air outlet }}
$$

\subsubsection{Solar Collector}

The area of the solar collector is determined through the analysis of the useful heat $\mathrm{Qu}$, limiting $50 \%$ of the total energy required to dry $7 \mathrm{~kg}$ of wet product.

Therefore, the equation will be related through the collector area $A_{c}$; the $F_{R}$ gain factor; the transmittance factor-effective absorptance $(\tau \alpha) ; G_{T}$, is the global radiation; $U_{L}$ is the global loss coefficient and the difference of input temperatures $T_{f e}$ and ambient temperature $T_{a}$ can be defined as [12].

$$
Q_{u}=A_{c} \cdot F_{R} \cdot\left[(\tau \alpha) G_{T}-U_{L} \cdot\left(T_{f e}-T_{a}\right)\right]
$$

The factor of gain $F_{R}<1$, as the efficiency comparison of a conventional exchanger, is defined as the coefficient between the actual transfer and the maximum possible transfer.

The coefficient of global heat loss $U_{L}$ is the sum of all coefficients of the roof, base, and sides of the solar collector.

On the other hand, the transmittance factor-effective absorptance $(\tau \alpha)$ depends on the absorptance (absorbent plate 0.9) and transmittance (for solar radiation, the transmittance is 0.95, while for the reflected radiation it is 0.1 ) [8]. In the case of reflectance, $\rho_{d}$ is about a constant 0.1 .

$$
(\tau \alpha)=\frac{\tau \alpha}{1-(1-\alpha) \rho_{d}}
$$

\subsubsection{Photovoltaic Systems}

The solar irradiation and relative humidity data of the area where the study was conducted were obtained from the METEONORM platform. The average annual solar radiation between 2014 and 2018 was approximately $4.14 \mathrm{Kw} \mathrm{h} / \mathrm{m}^{2} \mathrm{~d}$. Regarding the winds, these are of low intensity, and the longand short-term records indicate that the predominant direction of the winds is from the southwest, with a speed between 1 to $3.6 \mathrm{~m} / \mathrm{s}$ maximum. 
The sizing of the photovoltaic system is part of obtaining the direct radiation, diffuse, monthly albedo during the year, in order to determine the ability to determine the overall radiation inclined in the selected area [6].

$$
G_{T}=G_{b} \cdot R_{b}+G_{d}\left(\frac{1+\cos \beta}{2}\right)+\left(G_{b}+G_{d}\right) \cdot \rho_{g} \cdot\left(\frac{1-\cos \beta}{2}\right)
$$

where $G_{d}$ is the diffuse radiation; $\rho_{g}$ is the reflexibility or soil albedo; $\beta$ is the angle of the slope on the surface of the plate; $G_{b}$ is the direct radiation; and $R_{b}$ is the correction factor.

The optimum angle of inclination of the photovoltaic will be the one that optimizes the least solar radiation on the sloping surface throughout the year. In the case of Guayaquil, $\beta$, the inclinations were between 10 to 15 degrees. It should be noted that the worst month of the year is July, with $5.26 \mathrm{kWh} / \mathrm{m}^{2}$ d. Subsequently, the energy consumed throughout the system was estimated as being approximately $90 \mathrm{~W}$ of consumption.

\subsubsection{Aerothermal Exchangers}

The operation of the aerothermal system is based on the circulation of an airflow through the heat exchanger buried $70 \mathrm{~cm}$ from the surface of the soil, which results in an increase in the temperature of the working fluid, taking advantage of the heat capacity or the soil's ability to store heat. Subsequently, the working fluid enters the solar collector by raising the air temperature, before finally, the hot air enters the drying chamber.

For the design of the exchanger, it is necessary to determine the air outlet temperature as well as the maximum air flow flowing through the exchanger. This parameter will depend on the magnitude and characteristics of the diameter exchange surface, length, and number of tubes [13,14]. In Figure 1, the hybrid dryer components are shown.

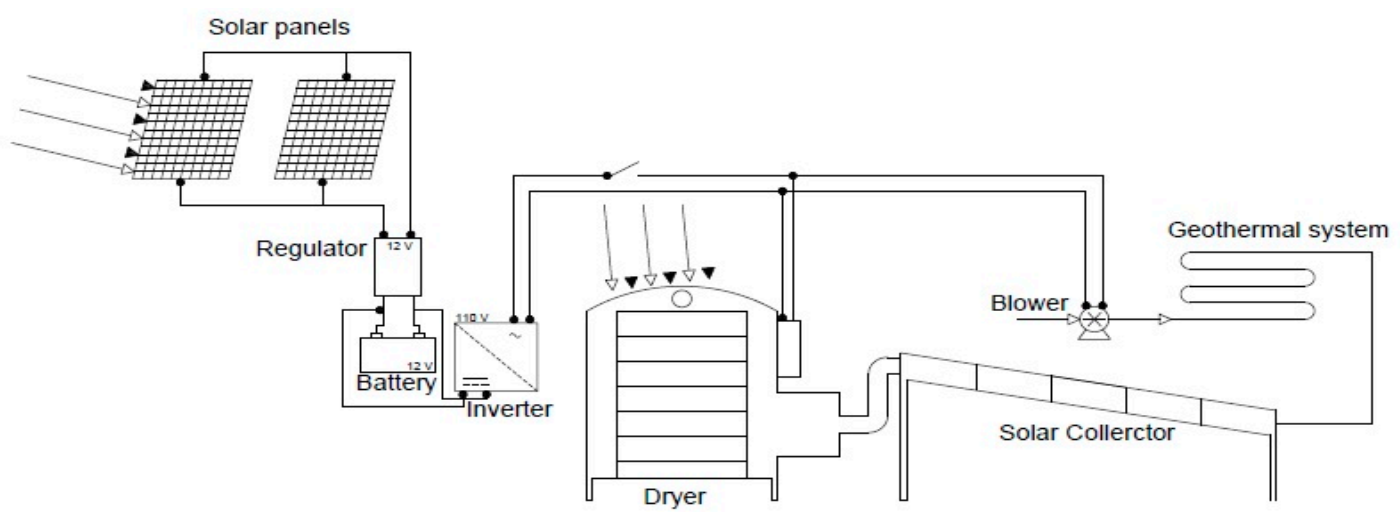

Figure 1. Scheme of the complements that are part of the hybrid dryer.

\section{Materials and Methods}

After the design and construction of the experimental prototype, the dryer was tested for operation. The first experimental tests were carried out under controlled conditions in a laboratory at constant ambient temperature with artificial irradiation produced by halogen lamps placed at different distances from the drying chamber. The objective of this test was to study each of the variables that will influence the operation of the prototype separately such as the chamber temperature, hot air flow, stability time, system homogeneity, and energy consumption, among other. It should be added that the above-mentioned procedure was replicated under environmental conditions, where irradiation conditions, humidity, and environmental temperatures are variable

Initially, a measurement protocol was performed as a standardized procedure, developed for the continuous recording of information throughout the different experimental tests. The main parameters measured in the system were: 
- Hot air temperature.

- Ambient air temperature.

- Air velocity.

- Flow of hot or drying air circulating through the tray assembly.

- Air flow the solar collector.

- Humidity at the inlet and outlet of hot air

- Ambient air humidity.

- Time.

- Solar irradiation.

- Energy consumption.

(a) Measuring instruments

- K-type thermocouples, connected to a data acquisition system datalogger brand "Pico Technology", model TC-08.

- The internal humidity of the chamber and external environment was measured with a $\mathrm{RH} /$ temperature datalogger and dew point "Lascar EL-USB-2".

- Air velocity was measured with the digital equipment "Testo 404-V1", Thermo hot wire anemometer.

- Global pyranometer connected to a digital multiple $(\mathrm{mV})$.

- Automatic control system connected to the dual channel thermostat (T2S+2C DIGIT), 6-channel temperature and humidity control inside the chamber, electrical fan control, and photovoltaic system protections.

(b) Drying chamber and solar collector

The drying chamber had an area of $150 \times 100 \times 100 \mathrm{~cm}$. Constructed of 304 stainless steel of $4 \mathrm{~mm}$ thickness. Internally, the camera was insulated with $10 \mathrm{~cm}$ thick glass wool. The front wall and ceiling were formed of $6 \mathrm{~mm}$ polycarbonate plates.

The solar collector was built of $430 \mathrm{~N} 4$ stainless steel of $0.040 \mathrm{~cm}$ and internally insulated with $10 \mathrm{~cm}$ thick glass wool. On the surface of the collector, we placed a commercial steel plate of $0.03 \mathrm{~cm}$, covered with black anticorrosive paint (black body). The cover of the collector was $3 \mathrm{~mm}$ thick transparent glass with a low iron content. The manifold was attached to the dryer chamber via a 3-inch tube.

(c) Photovoltaic systems

The photovoltaic system will supply a $65 \mathrm{~W}$ fan, dual channel thermostat (T2S+2C DIGIT) with a consumption of $5 \mathrm{~W}$, and an information acquisition system of $20 \mathrm{~W}$. It is estimated that $90 \mathrm{~W}$ of energy is needed. Therefore, a photovoltaic panel of $110 \mathrm{~W}$ peak power, voltage of $12 \mathrm{~V}$, short-circuit current Isc of $6.78 \mathrm{~A}$, and Voc open circuit voltage of $22.41 \mathrm{~V}$ was selected with a $12 / 24$ regulator, $250 \mathrm{~W}$ inverter, and 100 Ah battery.

(d) Aerothermia or buried horizontal catcher

This consists of a heat exchange probe with the subsurface constructed with $55 \mathrm{~m}$ of PVC tube with a diameter of $11 \mathrm{~cm}$. The exchanger was buried homogeneously in the subsoil at an approximate depth of $70 \mathrm{~cm}$, occupying an area of $21 \mathrm{~m}^{2}$. The installation will act as an auxiliary system for pre-heating the ambient air before it enters the drying chamber. The distance between the air inlet and outlet pipe was $3.5 \mathrm{~m}$. The air entering the exchanger is a forced flow that is generated through a blower with the size of 2", a voltage of $110 \mathrm{~V}, 4 \mathrm{~A}$, and 3000/3600 rpm. 
(e) Controlled conditions in the laboratory

The first test was to determine the stabilization time and uniformity of the temperature of the drying chamber and the collector, passing an airflow (forced convection) by using a ventilation system. For this test, $500 \mathrm{~W}$ halogen lamps were used, making configurations at a certain distance from the walls to generate irradiation of $300 \mathrm{~W} / \mathrm{m}^{2}, 400 \mathrm{~W} / \mathrm{m}^{2}, 500 \mathrm{~W} / \mathrm{m}^{2}, 600 \mathrm{~W} / \mathrm{m}^{2}, 700 \mathrm{~W} / \mathrm{m}^{2}, 800 \mathrm{~W} / \mathrm{m}^{2}$, $900 \mathrm{~W} / \mathrm{m}^{2}$, and $1000 \mathrm{~W} / \mathrm{m}^{2}$. The irradiation that reached the surface of the transparent plates was measured, to do so, it was necessary to make a square mesh $50 \mathrm{~cm}$ away for each point. During the test, the variables were recorded every $10 \mathrm{~min}$ during $2 \mathrm{~h}$ of chamber operation and then at the cooling stage (the luminaires are turned off) of one hour.

\section{(f) Environmental conditions}

Ecuador has two seasons: the rainy and humid season from December to May and the dry season from June to November where the annual total rainfall is approximately $1506.5 \mathrm{~mm}$ (INAMHI). Along the coast of the province, during the dry season (June-November) there are average temperatures from $21.65^{\circ} \mathrm{C}$ to $30.8^{\circ} \mathrm{C}$ with a humidity of 45 to $60 \%$, while in the rainy season (December-May), the average temperature is $30.65{ }^{\circ} \mathrm{C}$ with a humidity of 70 to $99 \%$. From the above, it is necessary to mention that the experimental tests were carried out from March to June.

The first test was to analyze the operation of the dryer in active mode (forced convection). The main variables recorded were the chamber temperature, temperature at the collector outlet, ambient temperature, and global irradiation that reached the transparent plates for a $10 \mathrm{~h}$ operating time.

For the second test, the operation of the aerothermal system during the day and night was evaluated in order to determine the temperature of the exchanger's stabilization and the temperature input of the soil. For this purpose, we placed type K thermocouples to record the temperatures of the soil at depths of $0.25 \mathrm{~cm}, 50 \mathrm{~cm}, 75 \mathrm{~cm}$, and $100 \mathrm{~cm}$.

Third test: During the experimental testing, the following parameters were measured: inlet and outlet temperature of the buried exchanger $T_{e, \text { aerothermal }} ; T_{s, \text { aerothermal }}\left({ }^{\circ} \mathrm{C}\right)$; relative humidity $(\%)$ and ambient temperature $\left({ }^{\circ} \mathrm{C}\right)$; the inlet and outlet temperature of the solar collector $T_{e, c o l}, T_{s, c o l}\left({ }^{\circ} \mathrm{C}\right)$; hot fluid velocity $(\mathrm{m} / \mathrm{s})$ at the exchanger outlet and in the drying chamber; chamber heating time(s); and global radiation on the ground surface, collector, and drying chamber $\left(\mathrm{W} / \mathrm{m}^{2}\right)$. Additional energy input generated through an electrical resistance of $1000 \mathrm{~W}$ was also measured.

On the other hand, parameters such as the energy consumption, voltage, and current supplied by the photovoltaic system were also recorded. It should be noted that the fan and the source of the control system was powered by photovoltaic energy. Finally, a test was performed on the hybrid dryer by coupling an electrical resistance as a complementary source for air heating.

\section{Results}

\subsection{Controlled Conditions in the Laboratory: Solar Dryer}

Experimental tests set the parameters that would allow us to understand the thermal response of the drying chamber with forced flow (turbulent flow) at an air rate of $1.5 \mathrm{~m} / \mathrm{s}$ and the variation of direct radiation. It should be noted that the speed set in the tests was the same as determined in the theoretical calculations. In addition, it should be noted that no direct irradiation tests were performed below $200 \mathrm{~W} / \mathrm{m}^{2}$, so that the operation of the dryer was low (heated up $5{ }^{\circ} \mathrm{C}$ more in relation to the ambient temperature). Finally, by performing the tests by triplicate, calibration errors of the instruments and measurement by the operator could be detected.

Figure 2 shows the operating results of the dryer for the different irradiations and thermal stability time of the chamber obtained from the multiple tests performed for an operating speed of $1.5 \mathrm{~m} / \mathrm{s}$. By adapting the drying chamber with the solar collector (Figure 2a), it was observed that the maximum temperatures reached at $300 \mathrm{~W} / \mathrm{m}^{2}$ were $37.5^{\circ} \mathrm{C}, 42.2^{\circ} \mathrm{C}$ to $400 \mathrm{~W} / \mathrm{m}^{2}, 46^{\circ} \mathrm{C}$ to $500 \mathrm{~W} / \mathrm{m}^{2}, 49.9^{\circ} \mathrm{C}$ to $600 \mathrm{~W} / \mathrm{m}^{2}, 55^{\circ} \mathrm{C}$ to $700 \mathrm{~W} / \mathrm{m}^{2}, 59.1^{\circ} \mathrm{C}$ to $800 \mathrm{~W} / \mathrm{m}^{2}, 65.5^{\circ} \mathrm{C}$ to $900 \mathrm{~W} / \mathrm{m}^{2}$, and $67.8^{\circ} \mathrm{C}$ to $1000 \mathrm{~W} / \mathrm{m}^{2}$, 
from the laboratory's ambient temperature of $27^{\circ} \mathrm{C}$. It can also be seen that the camera stabilized from $40 \mathrm{~min}$ from 300 to $500 \mathrm{~W} / \mathrm{m}^{2}$; from $600 \mathrm{~W} / \mathrm{m}^{2}$, the temperature stabilization time was one hour. On the other hand, during the cooling period, the chamber was estimated to have a decrease in the interior temperature between 1 to $2{ }^{\circ} \mathrm{C}$ every $10 \mathrm{~min}$ in the first hour. Subsequently, the internal temperature slowly decreased by an average value of $0.25^{\circ} \mathrm{C}$ every $10 \mathrm{~min}$ until the temperature loss curve slowly decreased. In Figure $2 b$, it can be observed that the maximum temperatures reached in the solar collector was $37^{\circ} \mathrm{C}$ to $300 \mathrm{~W} / \mathrm{m}^{2}, 40^{\circ} \mathrm{C}$ to $400 \mathrm{~W} / \mathrm{m}^{2}, 43^{\circ} \mathrm{C}$ to $500 \mathrm{~W} / \mathrm{m}^{2}, 46^{\circ} \mathrm{C}$ to $600 \mathrm{~W} / \mathrm{m}^{2}, 50{ }^{\circ} \mathrm{C}$ to $700 \mathrm{~W} / \mathrm{m}^{2}, 52{ }^{\circ} \mathrm{C}$ to $800 \mathrm{~W} / \mathrm{m}^{2}, 57^{\circ} \mathrm{C}$ to $900 \mathrm{~W} / \mathrm{m}^{2}$, and $59^{\circ} \mathrm{C}$ to $1000 \mathrm{~W} / \mathrm{m}^{2}$.

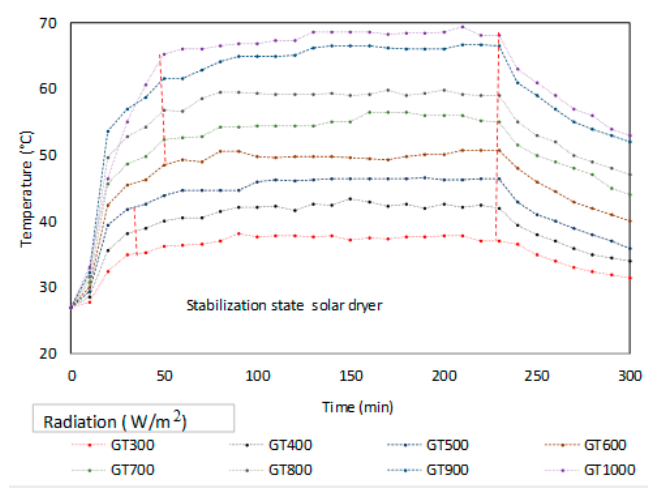

(a)

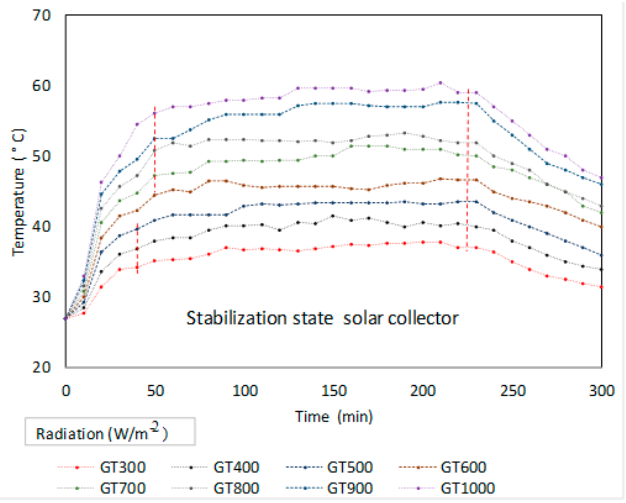

(b)

Figure 2. Average temperature reached in the (a) drying chamber and (b) solar collector.

Figure 3 presents the results of the temperature increase of the dryer in tests carried out under controlled conditions at an ambient temperature of $27^{\circ} \mathrm{C}$. A temperature increase in the drying chamber was achieved (Figure 3a) between 10 to $15{ }^{\circ} \mathrm{C}$ for irradiations between $300 \mathrm{~W} / \mathrm{m}^{2}$ and $400 \mathrm{~W} / \mathrm{m}^{2}$ (conditions of a cloudy sky). On the other hand, the linear trend presented by the data estimated a temperature increase of more than 18 to $23^{\circ} \mathrm{C}$ under conditions of a semi-cloudy sky $\left(500 \mathrm{~W} / \mathrm{m}^{2}\right.$ and $\left.600 \mathrm{~W} / \mathrm{m}^{2}\right)$; from $800 \mathrm{~W} / \mathrm{m}^{2}$, it can be considered as clear sky, which is a temperature increase of more than $28^{\circ} \mathrm{C}$. In relation to Figure $3 \mathrm{~b}$, it can be observed that the solar collector at low irradiations generated a temperature increase of 8 to $12{ }^{\circ} \mathrm{C}$ more in relation to the ambient temperature. In general, the energy input of the solar collector allows for the temperature of the drying chamber to be raised, in addition to keeping the system stable for longer once the lamps are turned off.

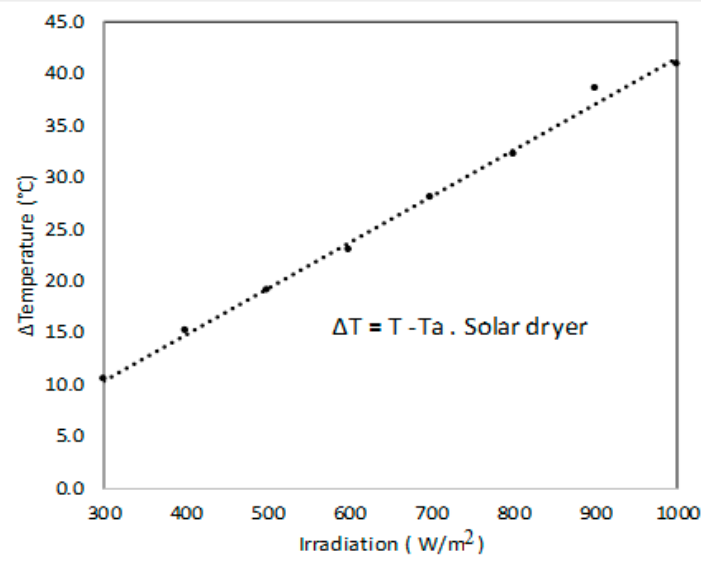

(a)

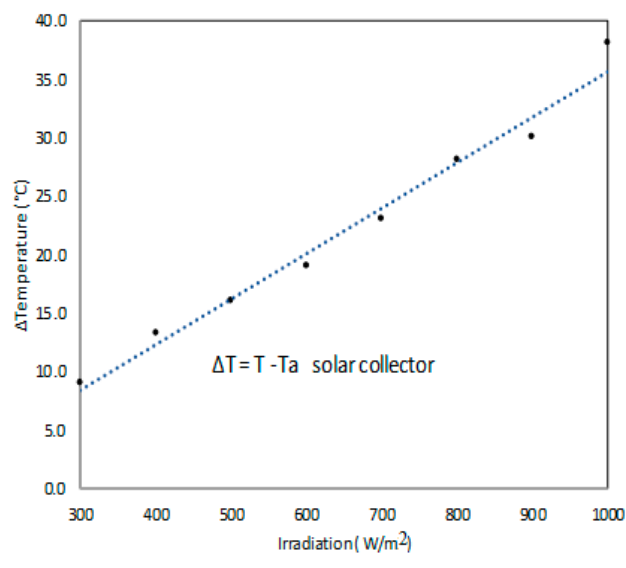

(b)

Figure 3. Difference between the internal temperature and the ambient temperature vs. irradiation in the (a) drying chamber, and (b) solar collector. 


\subsection{Evaluation of the Dryer and Solar Collector in Outdoor Conditions}

The first tests were performed only in the drying chamber, with a continuous flow of air inlet. The analysis evaluated the incident solar radiation and its influence on the warming of the internal air, heat supply, ambient temperature, air speed, and humidity, among other climatic conditions of interest, reaching an increase in temperature of $35^{\circ} \mathrm{C}$ on sunny days and an increase of $10^{\circ} \mathrm{C}$ on low irradiation days. The chamber response to the variation in solar radiation occurred with a delay of $10 \mathrm{~min}$, with the temperature loss and gain of less than $1{ }^{\circ} \mathrm{C}$.

Figure 4 shows the results obtained with the dryer chamber at different days under environmental conditions. The colors in the graph represent different measurement days. We can see that the solar dryer started at an ambient temperature between $25^{\circ} \mathrm{C}$ to $30^{\circ} \mathrm{C}$ and reached the design temperature of $50{ }^{\circ} \mathrm{C}$ with $450 \mathrm{~W} / \mathrm{m}^{2}$.

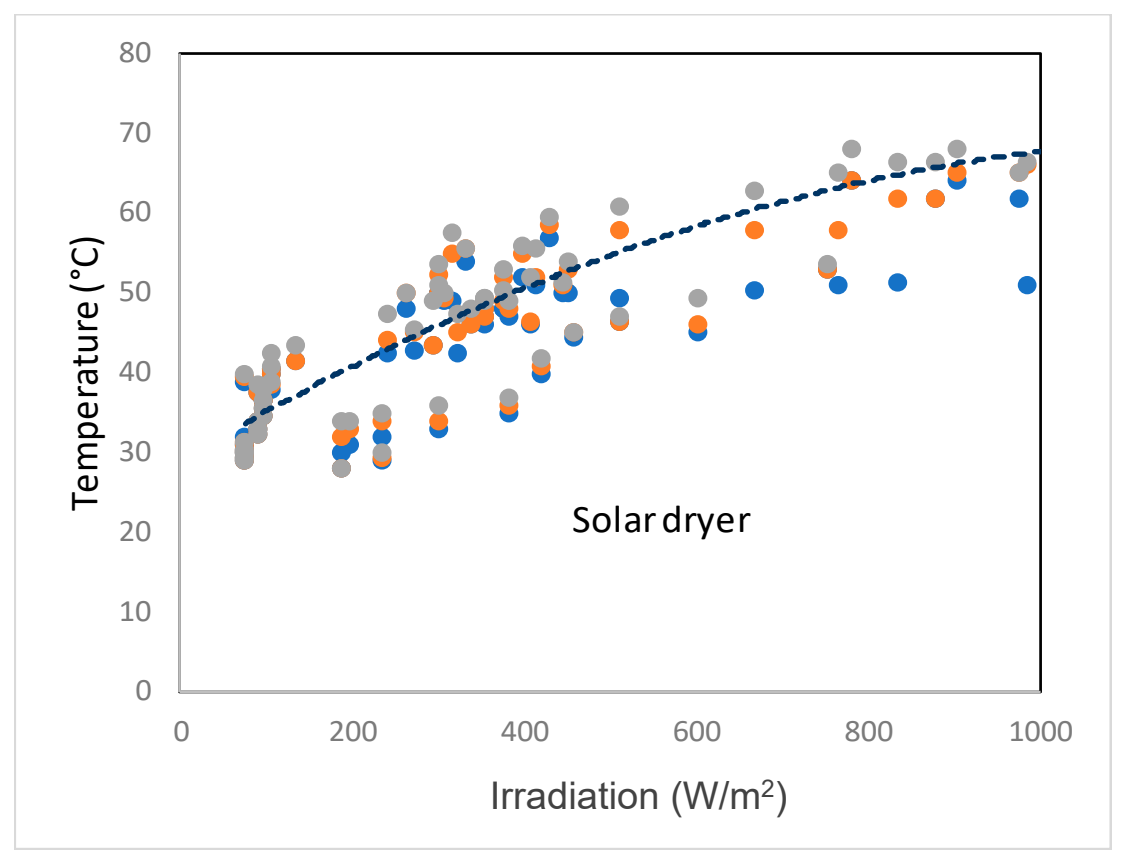

Figure 4. Measurements performed under environmental conditions for the solar dryer.

It is necessary to indicate that the experimental tests were carried out for four months (March to June) where the maximum ambient temperature of the locality ranges between $29^{\circ} \mathrm{C}$ and $36^{\circ} \mathrm{C}$ on the day.

Figure 5 analyses the influence of the solar collector on the drying chamber in real outdoor conditions. The stabilization intervals of the solar dryer were analyzed, especially at the global solar irradiation intervals of 300 to $800 \mathrm{~W} / \mathrm{m}^{2}$, where the air intake temperature in the solar collector (Te) was ambient temperature in a range of $27^{\circ} \mathrm{C}$ and an air velocity of $1.5 \mathrm{~m} / \mathrm{s}$. The temperature of the collector reached $50{ }^{\circ} \mathrm{C}$ from $500 \mathrm{~W} / \mathrm{m}^{2}$. 


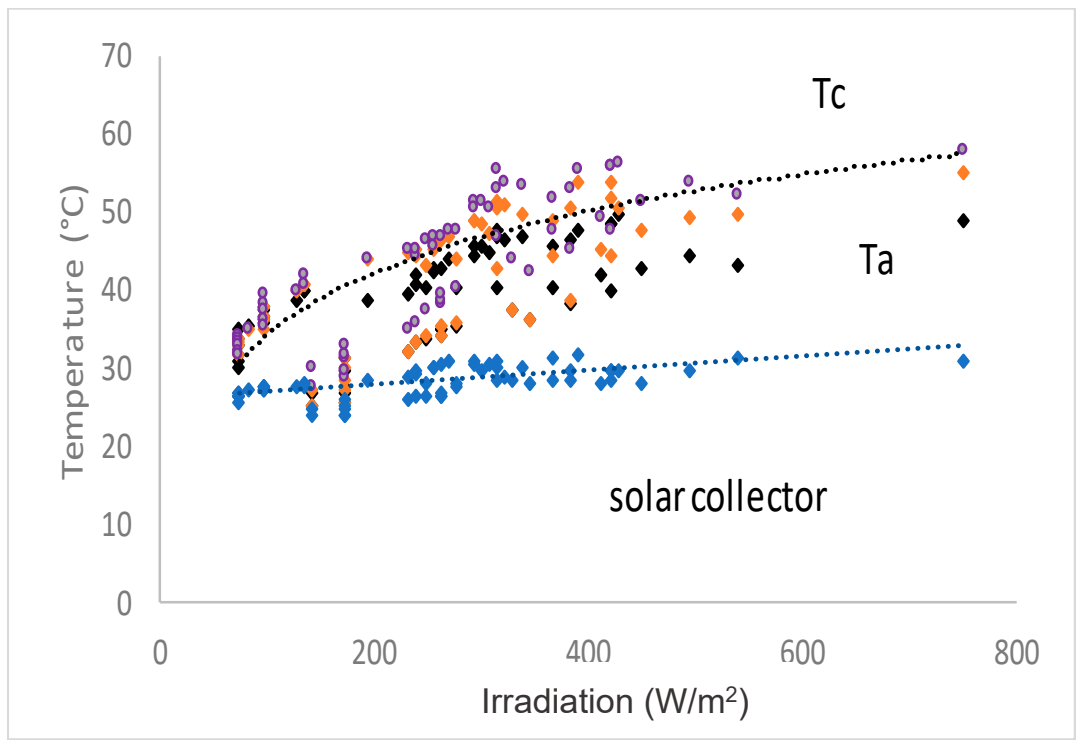

Figure 5. Measurements performed under environmental conditions for the solar collector,

\subsection{Experimental Testing of the Aerothermia SYSTEM}

Once the exchanger was installed at a depth of $70 \mathrm{~cm}$ from the surface of the ground, probes or thermocouples were placed at different depths. Temperatures were automatically recorded by the data acquisition system. Solar irradiation measurements were obtained from the ESPOL weather station database. Experimental data were measured over a week in ten-minute intervals.

Figure 6 shows an example of the daytime variation and thermal response of the soil measured at different depths to the wall of the heat exchanger over a day with an ambient temperature between 24 and $25^{\circ} \mathrm{C}$. It was observed that in the first surface centimeters (less than $20 \mathrm{~cm}$ ), there was a noticeable variation in temperature. However, as we went deeper, it was observed that the fluctuations in soil temperature were gradually reduced. In addition, the soil temperature had a sinusoidal tendency or behavior and its amplitude decreased depending on the depth, except for the surface temperature. In addition, temperatures below $20 \mathrm{~cm}$ deep remained relatively stable with values above the surface temperature at night.

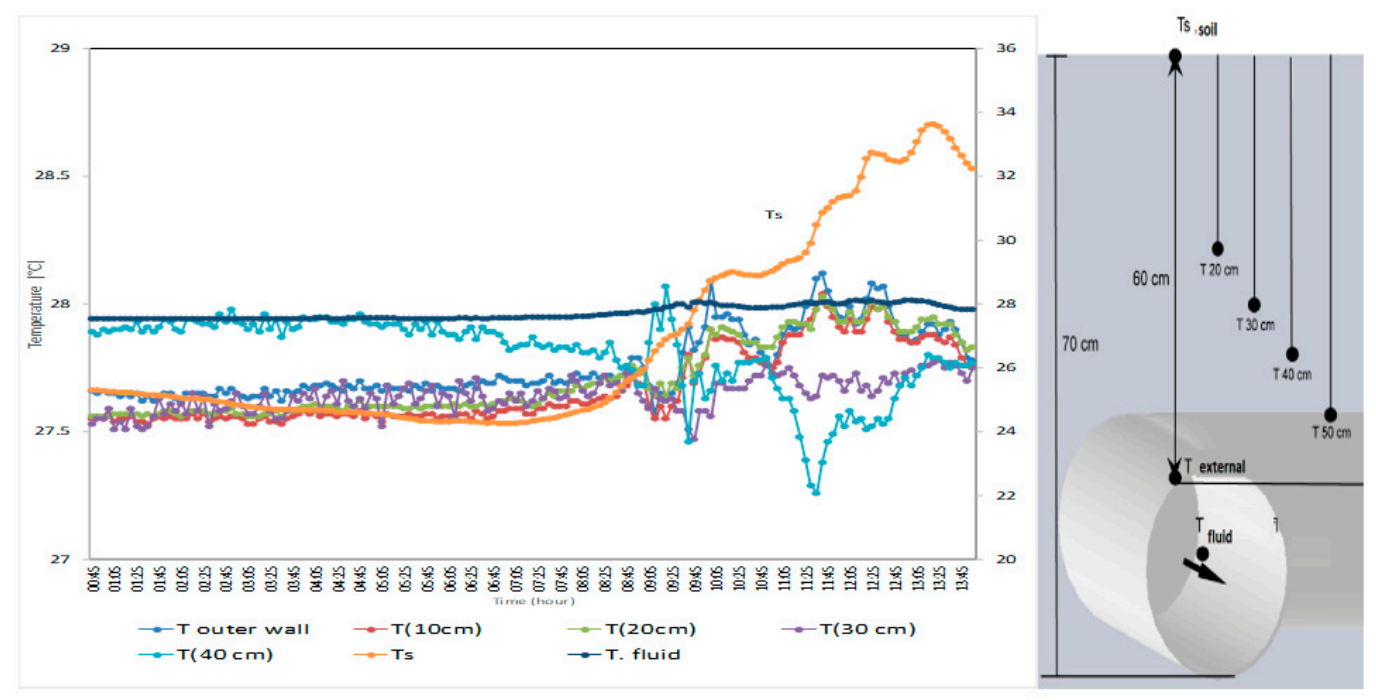

Figure 6. Soil surface temperature profile. 


\subsection{Experimental Testing of the Hybrid Dryer under Environmental Conditions}

Experimental tests of the operation of the dryer were carried out in a $12 \mathrm{~h}$ operation period, from 6:30 a.m. to $6: 30$ p.m., and we recorded the air velocity at the $1.7 \mathrm{~m} / \mathrm{s}$ exchanger outlet and the air velocity in the chamber was $1.3 \mathrm{~m} / \mathrm{s}$. Figure 7 shows the temperature of the drying chamber and the thermal gain of the collector depending on the irradiation. Moreover, it can be observed that the output temperature of the aerothermal was kept stable and does not depend on irradiation. It should be mentioned that it defines thermal gain as the difference between the output temperature of the collector and the temperature of the collector (output temperature of the aerothermal system). The main result noted was that in the hours of low irradiation, the energy input will depend mainly on the aerothermal system.

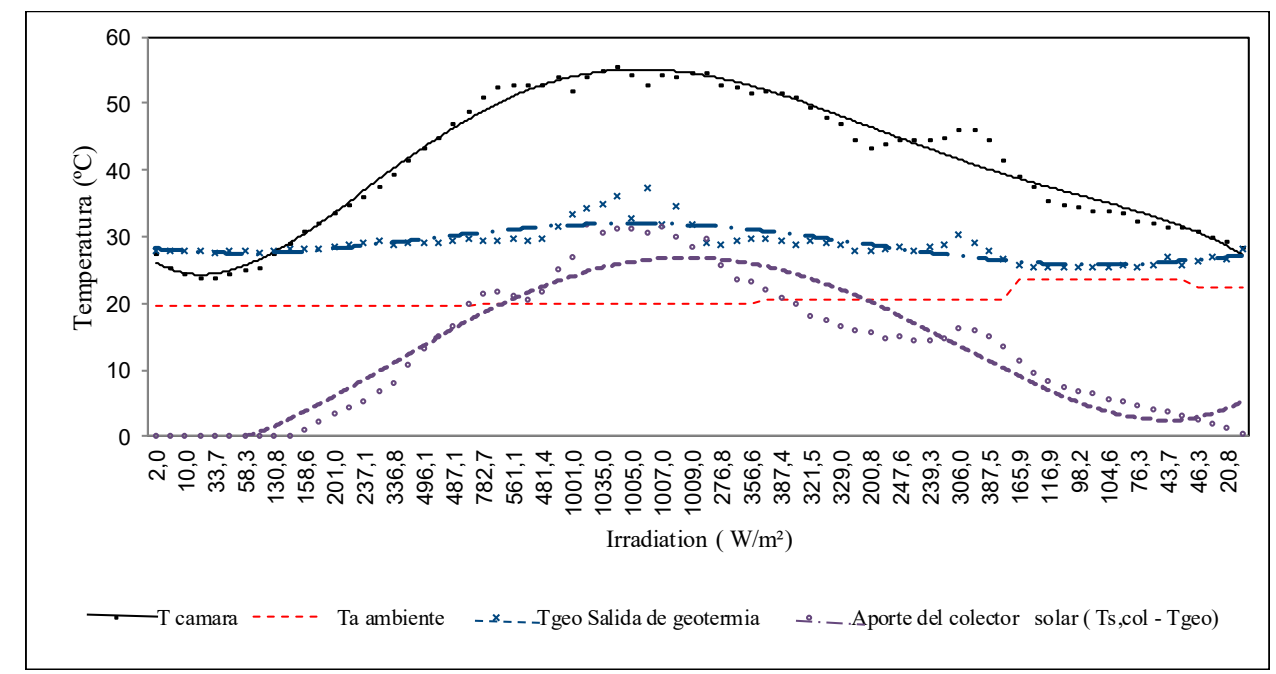

Figure 7. Operation of the solar dryer and the aerothermal system.

However, in the hours of increased irradiation, the dominant factor will be the solar collector. The system stabilization time at the operating temperature $\left(50{ }^{\circ} \mathrm{C}\right)$ was $50 \mathrm{~min}$ from $10 \mathrm{a} . \mathrm{m}$.

The energy balance of the system determined that the experimental thermal energy of the hybrid solar dryer varied between $1300 \mathrm{~W}$ and $2000 \mathrm{~W}$ when working in a solar radiation range of $400 \mathrm{~W} / \mathrm{m}^{2}$ to $1000 \mathrm{~W} / \mathrm{m}^{2}$, respectively. Figure 8 presents the results of the useful heat gained in the sustainable dryer.

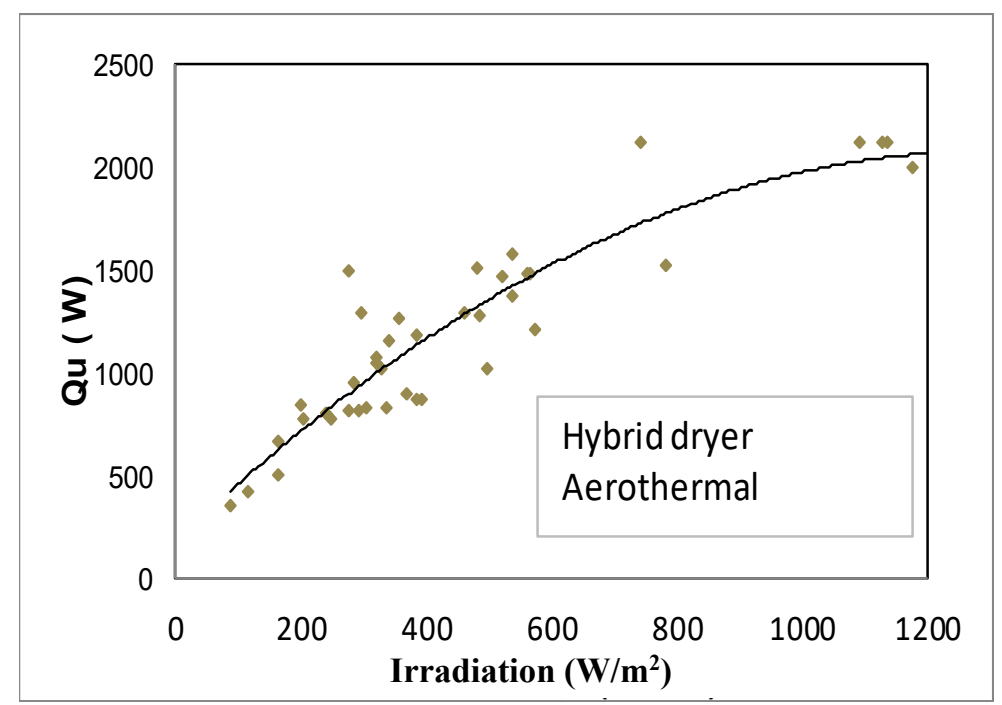

Figure 8. Heat gained in hybrid drying. 
The efficiency of the hybrid dryer is determined by the useful heat ratio of the drying chamber divided by the sum of energy resulting from the incident radiation in the chamber, solar collector, and exchanger. The influence of solar radiation related to the efficiency of the dryer is presented, and as can be seen in the results, the prototype showed an efficiency of around 60\% (Figure 9).

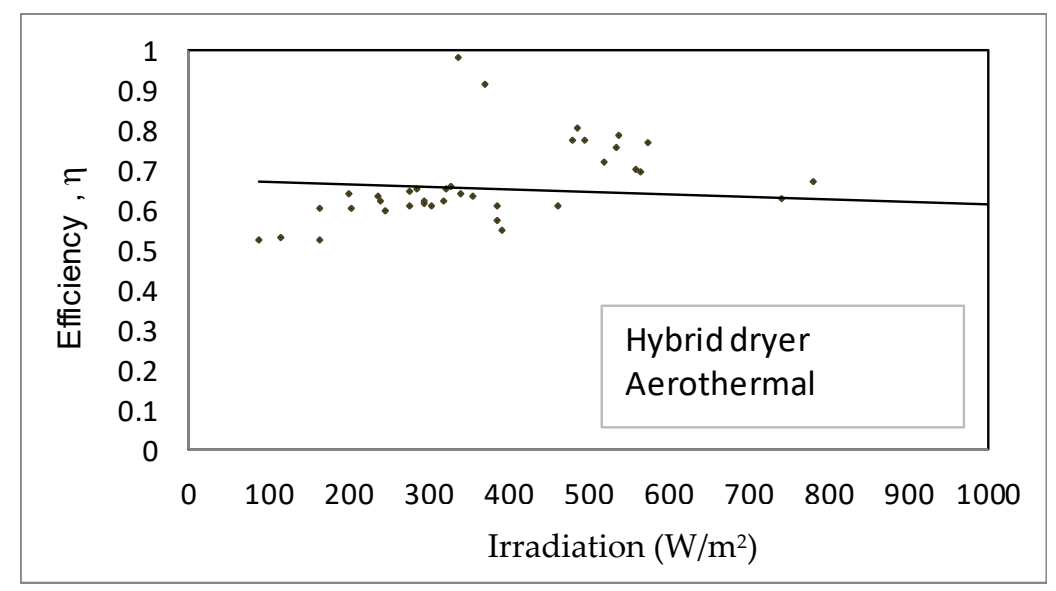

Figure 9. Efficiency of the hybrid dryer.

\subsection{Hybrid Dryer with Electrical Resistance}

As indicated above, the hybrid dryer with aerothermal reached its design temperature at $500 \mathrm{~W} / \mathrm{m}^{2}$, therefore it is essential to add another heat source, for example; an electrical resistance controlled by the control system of the dryer. It should be remembered that the photovoltaic system sized for the dryer supplies the fan and consumption of the control system for $10 \mathrm{~h}$ of operating the dryer. In Figure 10, an example of the operation of hybrid drying on a clear day with an average ambient temperature of $65 \%$, wind velocity less than $0.9 \mathrm{~m} / \mathrm{s}$, and solar radiation between 100 to $950 \mathrm{~W} / \mathrm{m}^{2}$ is presented. It was observed that the auxiliary system (electrical resistance) operated in the first hour of operation of the equipment until it reached the design temperature $\left(50^{\circ} \mathrm{C}\right)$; from $3 \mathrm{~h}$ of operation, the resistance operated in short periods of time to maintain the chamber temperature. Additionally, when the solar radiation was between 500 to $950 \mathrm{~W} / \mathrm{m}^{2}$, the dryer will be powered by the solar collector. As the radiation drops, the auxiliary system will go into operation to keep the internal temperature constant. Electricity consumption from the operation of the electrical resistance was $5 \mathrm{~kW} /$ day (in continuous operation, the resistors will consume a total of $10 \mathrm{~kW} /$ day).

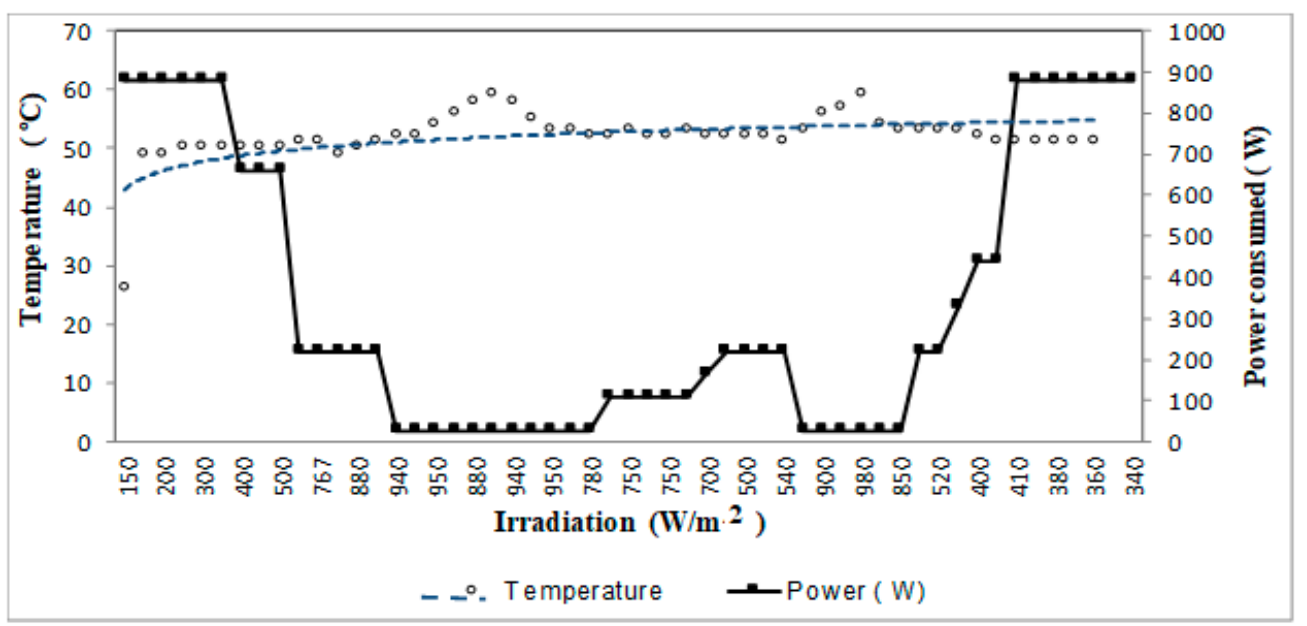

Figure 10. Hybrid dryer at work using solar energy, aerothermal, and an auxiliary system (electrical resistance). 


\section{Discussion and Conclusions}

Ambient temperature and irradiation is one of the factors that can drastically affect the operation of a solar dryer. When analyzing the drying chamber without a heat dissipation medium, it was observed that on very bad days, the maximum internal temperature increase of the reached chamber was $10^{\circ} \mathrm{C}$. Therefore, adapting another energy source that compensated for the design temperature was justified to maintain the kinetics of the constant drying of the product.

The stability time of the experimental prototype was $40 \mathrm{~min}$ for the solar dryer and hybrid solar-system. As expected in a solar dryer, running only as a greenhouse effect means that the stability time of the chamber is longer. Furthermore, we checked the good thermal resistance of the materials used in the structure of the drying chamber.

In the case of adapting a low enthalpy horizontal geothermal system in the prototype, it was determined that in the hours of low irradiation, the energy input will depend mainly on the aerothermal system. However, in the hours of increased irradiation, the dominant factor will be the solar collector.

Testing on the models determined that the best results were obtained in hybrid mode with an aerothermal system where an efficiency of $60 \%$ to $70 \%$ was observed. Moreover, it was determined that the efficiency of the solar dryer with the collector was 30 to $60 \%$.

The proposed photovoltaic installation allowed us to meet the energy demand of the $95 \mathrm{Wp}$ electrical system in total by keeping a fan and the control system on.

The energy consumption of the auxiliary system on days with clear sky will be minimal, therefore operating the dryer most of the time only with the contribution of solar radiation. However, it is evident that the constant use of the power source on very bad days, on the other hand, where energy savings in electricity consumption between 3 to $5 \mathrm{~kW} /$ day were achieved.

Regarding the soil profile (geothermal energy), our results indicate that the temperature remained stable at a depth of $70 \mathrm{~cm}$, with an increase of $5^{\circ} \mathrm{C}$ more in reference to the ambient temperature at night, while during the day, the temperature increase of the air was 10 to $14^{\circ} \mathrm{C}$. The soil temperature had a sinusoidal tendency or behavior, and its amplitude decreased depending on the depth, with the exception of the surface temperature.

The change in the energy matrix of Ecuador promotes the implementation of renewable energy in the framework of distributed energy systems as a mechanism to achieve sustainable development and an important alternative with impacts in the social and economic development of the Ecuadorian population. The dryer built in this study meets these requirements, and could be considered as an alternative solution for local development to be used by small and medium industries that need to dry their products

Author Contributions: E.D.-P. and J.P.-J. methodology, design, analyses, and interpretation of data, writing - original draft preparation; J.R.-T. measurements; M.Q. and M.P. investigation; A.A. simulation and analysis; M.A. and O.G. measurements; B.V.-M. formal analysis and review.

Funding: This research was funded by SENESCYT "National Secretary of Higher Education, Science and Technology".

Acknowledgments: (Risiged) Iberoamerica network of hybrid systems of distributed generation. Cited.

Conflicts of Interest: The authors declare no conflict of interest.

\section{References}

1. Fito-Maupoey. Introducción al Secado de Alimentos Por Aire Caliente, 2nd ed.; Editor Universidad Politécnica de Valencia: Valencia, Spain, 2001; Volume 3, pp. 4-20.

2. Billiris, M.A.; Siebenmorgen, T.J.; Mauromoustakos, A. Estimating the theoretical energy required to dry rice. J. Food Eng. 2011, 107, 253-261. [CrossRef]

3. Billiris, M.A.; Siebenmorgen, T.J. Energy Use and Efficiency of Rice-Drying Systems II. Commercial, Cross-Flow Dryer Measurements. Appl. Eng. Agric. 2014, 30, 217-226. [CrossRef] 
4. Guaman, T. Diseño Concurrente de una Secadora Vertical Intermitente Para Arroz, 1st ed.; Editor ESPOCH: Chimborazo, Ecuador, 2010; Volume 1, pp. 25-30.

5. Delgado-Plaza, E.; Quilambaqui, M. Assessment of drying technology for rice, corn and cocoa products in Guayas and Los Rios province. Magazine Engineering, ICT's and industrial processes. In Proceedings of the REDU Congress VI, Ibarra, Ecuador, 14 November 2018; pp. 664-676.

6. Delgado-Plaza, E. Diseño, Modelo Matemático Y Construcción de un Secadero Optimizado Con Energías Limpias, 1st ed.; Editor USC, Santiago de Compostela: Coruña, España, 2015; Volumen 1, pp. 40-60.

7. Delgado-Plaza, E. Modelamiento y Análisis de secaderos con aplicaciones a fuentes de energía alternativa utilizando programa de simulación. In Proceedings of the III CAIM: Tercer Congreso Argentino de Ingeniería, Mecánica, Buenos Aires, Argentina, 11 November 2012.

8. Fudholi, A.; Sopian, K.; Ruslan, M.H.; Alghoul, M.A.; Sulaiman, M.Y. Review of solar dryers for agricultural and marine products. Renew. Sustain. Energy Rev. 2010, 14, 1-30. [CrossRef]

9. Sami, S.; Etesami, N.; Rahimi, A. Energy and exergy analysis of an indirect solar cabinet dryer based on mathematical modeling results. Energy 2011, 36, 2847-2855. [CrossRef]

10. El-Sebaii, A.A.; Shalaby, S.M. Solar drying of agricultural products: A review. Renew. Sustain. Energy Rev. 2012, 16, 37-43. [CrossRef]

11. Singh, S.; Kumar, S. Testing method for thermal performance based rating of various solar dryer designs. Solar Energy 2012, 86, 87-98. [CrossRef]

12. VijayaVenkataRaman, S.; Iniyan, S.; Goic, R. A review of solar drying technologies. Renew. Sustain. Energy Rev. 2012, 16, 2652-2670. [CrossRef]

13. Aroca-Delgado, R.; Pérez-Alonso, J.; Callejón-Ferre, Á.J.; Velázquez-Martí, B. Compatibility between Crops and Solar Panels: An Overview from Shading Systems. Sustainability 2018, 10, 743. [CrossRef]

14. Delgado, E.; Peralta, J. Análisis de un sistema de aerogeotermia de baja entalpia. In Proceedings of the 14th LACCEI International Multi-Conference for Engineering, Education, and Technology: Engineering Innovations for Global Sustainability, San José, Costa Rica, 22 July 2016; pp. 24-26. [CrossRef]

(C) 2019 by the authors. Licensee MDPI, Basel, Switzerland. This article is an open access article distributed under the terms and conditions of the Creative Commons Attribution (CC BY) license (http://creativecommons.org/licenses/by/4.0/). 